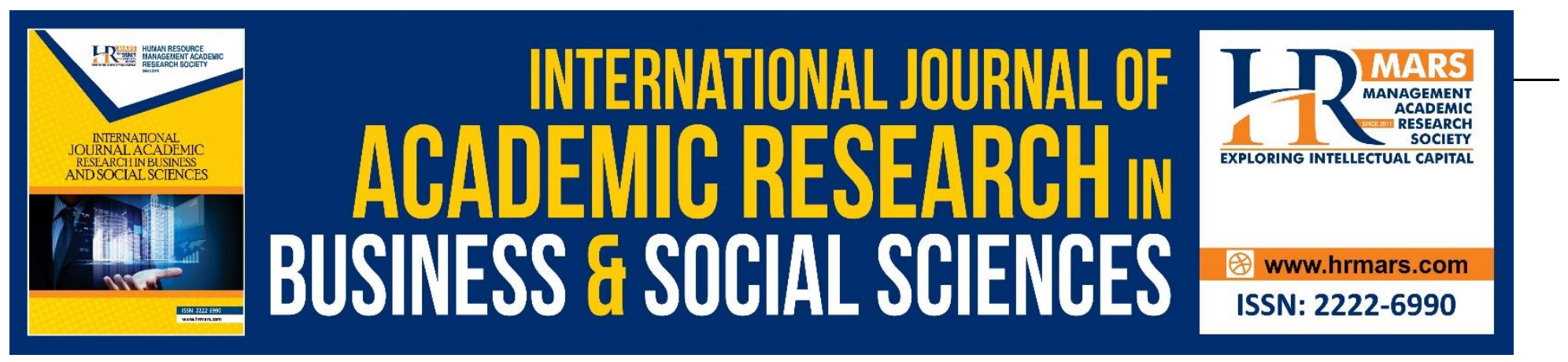

\title{
Critical Success Factors CSFs to Automation and Robotics in Industrialized Building System IBS
}

Mohd Najib Abd Rashid, Mohd Rofdzi Abdullah, Dzulkarnaen Ismail

To Link this Article: http://dx.doi.org/10.6007/IJARBSS/v8-i12/5432

DOI: $10.6007 /$ IJARBSS/v8-i12/5432

Received: 21 Nov 2018, Revised: 29 Dec 2018, Accepted: 04 Jan 2019

Published Online: 06 Jan 2019

In-Text Citation: (Rashid, Abdullah, \& Ismail, 2018)

To Cite this Article: Rashid, M. N. A., Abdullah, M. R., \& Ismail, D. (2018). Critical Success Factors CSFs to Automation and Robotics in Industrialized Building System IBS. International Journal of Academic Research in Business and Social Sciences, 8(12), 2207-2221.

Copyright: (C) 2018 The Author(s)

Published by Human Resource Management Academic Research Society (www.hrmars.com)

This article is published under the Creative Commons Attribution (CC BY 4.0) license. Anyone may reproduce, distribute, translate and create derivative works of this article (for both commercial and non-commercial purposes), subject to full attribution to the original publication and authors. The full terms of this license may be seen at: $\underline{\text { http://creativecommons.org/licences/by/4.0/legalcode }}$

Vol. 8, No. 12, 2018, Pg. 2207 - 2221

Full Terms \& Conditions of access and use can be found at http://hrmars.com/index.php/pages/detail/publication-ethics 


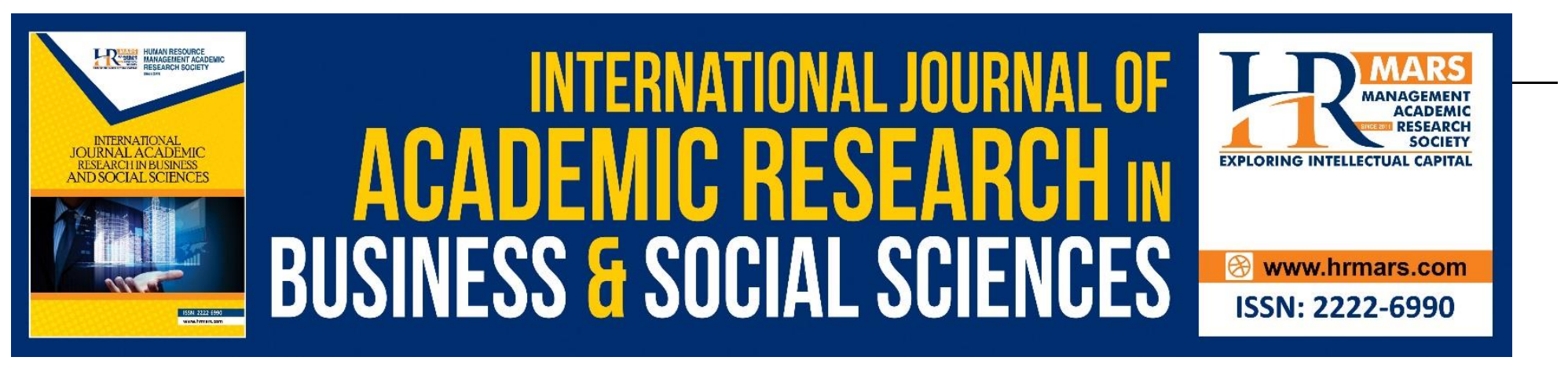

\title{
Critical Success Factors CSFs to Automation and Robotics in Industrialized Building System IBS
}

\author{
Mohd Najib Abd Rashid, Mohd Rofdzi Abdullah, Dzulkarnaen \\ Ismail
}

Fakulti Seni Bina, Perancangan \& Ukur, Universiti Teknologi MARA Cawangan Perak, Malaysia.

\begin{abstract}
The construction industry demands active construction organisations, efficient construction processes and innovative construction techniques to effectively compete under increasing globalisation, market competition and technological advancements in the twenty-first century. The problems of industrialised building system (IBS) associated with construction such as decreasing quality and productivity, unskilled labour, occupational safety, and inferior working conditions have opened the possibility of more revolutionary solutions within the industry. One of the prospective options is in the implementation of innovative technologies in construction such as automation and robotics, which has the potential to improve the industry regarding productivity, safety and quality. The Objective of this paper is to identify the critical success factors to automation and robotics in the Industrialised Building System to overcome the problems highlighted which can benefit the Malaysian Construction Industry as a whole. Keywords: Automation, Robotics, Industrialised Building System, Critical Success Factors CSFs
\end{abstract}

\section{Introduction}

The Malaysian Construction Industry Master Plan (CIMP 2006 - 2015) highlights the critical issues of Industrialized Building System (IBS) is productivity. The problems of productivity in the Malaysian construction industry is still the major issue in the industry such as productivity, dependency on foreign workers and high level of construction wastage (Azman \& Nawi, 2014). Despite the potential of IBS, the adoption and uptake on IBS in the Malaysian construction industry are low. Study conducted by (Kamar et al 2014; Mohd Amin et al., 2017) stated that in 2003 and 2005 that only $15 \%$ of the construction projects used IBS in Malaysia, and the survey also indicated that only approximately $10 \%$ of the complete projects used IBS in 2006 as compared to the forecasted IBS usage of $50 \%$ in 2006 and $70 \%$ in 2008, as projected in the IBS roadmap initiatives. In a press statement by the CIDB General Manager of the IBS \& Mechanization Division, Technology Development Sector, Noraini Bahri stated that, as at 31st December 2015 , only about $42 \%$ of public projects Malaysia use modern Industrialised Building 
Systems (IBS) technology. Furthermore, when the target of the IBS Roadmap 2011- 2015 is to have all public projects to obtain an IBS score of 70 or more, the IBS usage in public projects fell below expectations, with only $24 \%$ of public projects valued at above RM10 million have an IBS score of 70 or more. To date, as at May 2016, Works Minister, Datuk Fadillah Yusof said that about $69 \%$ of government projects used IBS, while the adoption rate by the private sector is still low around 14\% (CIDB, 2018; Dewan Rakyat, 2017).

Rashidi \& Ibrahim, (2017) consequently, stated that the construction industry records low productivity levels in comparison with other sectors in Malaysia. The local and global labour productivity benchmarks reported in the CITP 2016-2020 reflect the limited modernisation in Malaysian construction methods and practices, as well as a reliance on a low-skilled workforce. With the problem of housing becoming increasingly serious as a result of using conventional construction methods, the Malaysian construction authorities are actively trying to utilise new technology and promote the adoption of modern practices of construction to meet the planned targets planned under the 11th Malaysian Plan. Therefore, it is crucial to encourage the uptake of IBS through industrialised construction work by increasing technology and modern Practices focusing on Automation and Robotics (Abd Rashid et al., 2018; CIDB, 2015).

The methodology adopted is primarily based on a thorough review of the relevant literature on CSFs within the scope of automation and robotics in the Industrialised Building System (IBS). All the data and information gathered directly from libraries, books, articles and other printed materials searched in the international and national journals, proceeding and bulletin.

\section{Critical Success Factors CSFs to Automation and Robotics in IBS}

Critical success factor was first introduced by Richard Daniel back in 1960. In the study, he had discussed the problem of inadequate management information for setting objectives, shaping strategies, making decisions, and measuring results against goals. Daniel asserted that organisational planning information should focus on "success factors," which he described as "three to six factors that determine success...important jobs that must be done exceedingly well for a company to be successful" (Fritz, 2006). Amberg, Fischl, \& Wiener (2005) stated that the CSF approach to identifying and measuring an organisation's performance was developed and became well established under the work of Rockhart (1979). Rockart \& Bullen (1981) define the CSFs are the limited number of areas in which satisfactory results will ensure successful competitive performance for the individual, department or organisation. In the context of IBS particularly automation and robotic, CSFs are the key areas to be identified and for the goals to be attained. Therefore, this study had identified 28 critical success factors to automation and robotics in industrialised building system that will be discussed in details in the next section. 


\section{Good Working Collaboration}

A good working collaboration with all parties from the design, manufactured and construction/installation will ensure the success of automation and robotics (Ismail, Yusuwan, \& Baharuddin, 2012). It will solve the problem related to complex interfacing between systems and ensure efficient process sequence in design, manufacturing and construction/installation (Kamar et al., 2014). A study conducted by (Meynagh et al., 2014; Yunus et al., 2017) confirmed the good working collaboration is crucial to ensure the success of automation and robotics.

\section{Effective Communication Channel}

Communication channels refer to the way the information flows within the organisation and with other organisations. In construction, effective communication channel between all parties in the initial works of IBS process is essential to ensure the success of IBS project implementation (Ismail et al., 2012). The automation and robotics will enable effective prefabrication, delivery and supply of components to be undertaken according to the project schedule (Čuš-Babič et al., 2014; Kamar et al., 2014; Nawi et al., 2016; Yusof et al., 2015)

\section{Coordination of design, Manufacture, Transportation and Installation}

Automation and robotics increase coordination of planning throughout the project lifecycle in terms of design, manufacturing, transportation and installation which generally regards as difficult by the contractors due to the nature of the construction industry, which, is fragmented, diverse and involve many parties (Čuš-Babič et al., 2014; Nawi et al., 2016; Tajul et al., 2017).

\section{Involvement during design stage for all team members}

The involvement of all team members during the design stage will improve project performance through a reduction of wastage in schedule, cost and adversarial relationship issue (Nawi et al., 2010) reduce the likelihood of creating designs that cannot be efficiently built, thereby reducing design rework, improving project schedule, and establishing construction cost saving (Nawi et al., 2014). This involvement only is successful through the use of automation and robotics (Andersson \& Lessing, 2017).

\section{Experienced workforce and Technical capable}

Availability of experienced professionals \& skilled workforce/staff is a critical success factor in automation and robotics (Silva et al., 2016). Automation and robotics in IBS require an experienced workforce capable of high-level planning, organising and controlling functions to production, coordination and distribution of components. Jabar et al. (2013) stated that the workforce should be competent and experienced in managing the automation and robotics construction activities (Kamar, 2011; Yusof et al., 2015). 


\section{Information and communication technology (ICT)}

The Information and Communication Technology (ICT) is a vital and reliable support tool towards automation and robotics to improve the design, tendering, planning, monitoring, distribution, logistics and cost comparison process by establishing integration, accurate data and effective dealing with project documents (kamar et al., 2009; Yusof et al., 2015).

7. Risk management Strategy

Hassim \& Jaafar, (2009) stated that the risk has been defined as the probability of occurrence of some uncertain, unpredictable and even undesirable event(s) that would change the prospects for the profitability on a given investment. The success of automation and robotics investment depends very much on the efficient and effective management of the risks involved. Developed countries have extensive experience in managing risks because of lessons from their success and failure of automation and robotics in the construction industry. The potential loss from risks is the primary factor that hinders automation and robotics in IBS application by decision makers who lack experience in this field (Luo et al., 2015)

\section{Extensive planning and scheduling}

Extensive planning and scheduling of activities in advance is critical which will lead to better project performance, coordination, better scope control and ensure smooth project sequence (Kamar et al., 2014; Yusof et al., 2015).

\section{Management of supply chain}

High demands on the management of supply chain and logistics activities. It needs to be coordinated in a manner that allows constructors to gain the full control of the process with the intention to improve efficiencies and competitiveness (Meynagh et al., 2014; Yusof et al., 2015).

10. Top-down commitment

Yusof et al. (2015) stated that the implementation of automation and robotics in IBS also depends on 'top-down' commitment and corporate motivation. In return, this will ensure the right motivation and commitment from the whole team. Kamar et al. (2012) stated that Vision and commitment from the board management is the most critical factor determined the success of automation and robotics in IBS, followed by early decision to use automation and robotics in IBS

\section{Economic of scale}

Bock et al., (2014) stated that the economies of scale bring benefits to productivity and help reduce production costs. The economies of scale through the widening of the operating market and repetitive use of the technologies will enable higher investments in acquiring the technologies (Mahbub, 2008). (Buckett, 2013) To achieve economies of scale, the industry had to target higher-value housing, going mid - to upmarket. This marketing strategy played on the higher quality controls, strengths, consistency of product and ability to 'customise' the housing with a multitude of options to personalise the product. 


\section{Partnering}

Partnering with suppliers, manufacturers, contractors and subcontractors from the early stages was essential to ensure the efficient and timely delivery of components and services. Strategic partnering has suited both large and small firms allowing numerous opportunities to improve their conduct of business such as wider diffusion of products without costly physical presence in the markets, risk and reward sharing, resource pooling, reduction in the coordination and transaction cost, ability to concentrate on core competency and rapid response to market needs. This factor is also essential to those industry players who are not familiar with the automation and robotics to merge with experienced companies through a partnering approach (Kamar \& Hamid, 2011; Lou et al., 2012)

\section{Standardisation}

Automation and robotics required standardisation as stated by Buckett (2013) without standardisation of sizes; there is a limited ability for automation and robotics to lower costs. Conversely, without significant cost benefits, there is little gain from using standardisation designs. CITP 2016-2020 urge the adoption of various construction technologies that promote standardisation can lower upfront procurement costs while higher quality construction will reduce expenditure directed towards re-work, maintenance, renovations and repairs. At the same time, a more resource-efficient approach to construction will drive further savings. UK-RAS Network, (2016) also stated the key drivers for the success of automation and robotics came from the standardisation of manufacturing processes that improved the quality of consumer products. Xue et al., (2017) on the other hand suggested that standardisation design promoted mass production and that economies of scale can reduce the cost of products. This is because standardisation can improve the proficiency and productivity of the workers, and reduce the labour cost.

\section{Building Information Modelling (BIM)}

BIM, 3D modelling software, can resolve many technical difficulties in the precast construction processes. For instance, with the adoption of BIM in the prefabricated concrete industry, engineering cost is reduced, the cost of rework due to errors are tremendously reduced. Besides, it was stated that further improvement of manufacturing technology is a reliable solution to tackle the weakness and threats of IBS adoption (Soon Ern et al., 2017). The integration of design, manufacturing, and construction processes, and transparency of information about material resources across these processes would bring significant benefits for all stakeholders within the supply-chain (Čuš-Babič et al., 2014). 
15. Virtual Reality (VR)

With the rapid development of technologies, the virtual reality application also considers as success factors to automation and robotics. As stated by Dallasega, Rauch, \& Linder, (2018) Virtual Reality or Mixed Reality can increase customers' understanding of the final product early in the design phase to avoid wasteful changes during project execution. Bock (2006) also added that virtual reality application makes sure that customers do not become confused by the huge amount of choice, they can use virtual reality to walk through their dream home and can change anything they do not like before they sign the contract. If they approve of the simulation of the house and agree with the price and the financing terms, the CAD/CAM system starts to manufacture the components and room cells, which leaves hardly any waste. Virtual reality also enables product managers and designers to see new ideas either through advanced computeraided design or 'Virtual Reality' (Alinaitwe et al., 2006).

16. Improved Speed to the market

Tasks are performed more quickly compared to manual methods. They provide consistent and predictable productivity that reduces management oversight. The 24-hour production cycle is a good advantage of robotics helping with production cost reduction and better sustainability (Ogbemheet al., 2017).

17. Scaling and adapting to changing demand/Flexibility

Robots perform more tasks due to software and perception technology that has expanded its capabilities. Programming robots have become more accessible than in the past so that programmers can source and trained in-house. A robot can be automated numerous tasks in a single setup - easing transition time, training and space requirements (Ogbemhe et al., 2017)

18. Delivering consistent Demand

Robotic movements are consistent, focused and with high precision. It avoids productivity loss and re-work that tends to happen late in a shift or work week due to fatigue. The quality scales up without the challenges of finding skilled workers to maintain it (Ogbemhe et al., 2017).

19. Return on investment through cost reduction and added value

The capital expense can quickly be recovered due to the increased product and profit sales that emanate from the robot's high productivity. Training and maintenance cost for robotic systems are lower than that of staffs. The life cycle of a robot can last beyond its break-even threshold. The high-quality production and predictability associated with the use of industrial robot lead to increase margin (Ogbemhe et al., 2017; Prasath Kumar et al., 2016). 
20. Availability of Plant and Equipment/Machineries/Technology Idoro, (2012) consider equipment availability as one of the factors that affect productivity. Alinaitwe et al. (2009) opine that the main reason that productivity growth has been poor is the level of technological change in the industry. To ensure the success of automation and robotics in IBS the plant, equipment, machinery and technology is available locally or internationally.

\section{Demand and Market Factors}

Son et al., (2010) stated that the use of automation and robotics technology spurs market growth through the provision of new or improved products and services as well as reductions in the cost of production. Market acceptance can be gained if automation and robotics enable giving the customers the feeling that they can implement individual housing needs without extra charges or at reasonable costs and without delays (Vähä et al., 2013). There is an evident by looking the market share, where industrialisation of the construction industry has indicated a high potential of progress to the industry in the developed countries (Abd Hamid et al., 2017).

\section{Government Initiatives}

Some direct and indirect economic benefits can be gained from the utilisation of automation and robotics to assist, collaborate, or replace human labour. Immediate economic benefits primarily involve savings in labour cost, resource cost, and cost waste management, while indirect economic benefits refer to saving in time, rework reduction, improved building quality, and possible government incentives for applying innovation (Pan et al., 2018a). Incentive from the government for example Automation Capital Allowance (ACA), Reinvestment loan (RA), Domestic Investment Strategic Fund (DISF) under MIDA should be considered by the organisation to enhance the automation and robotics in IBS (MIDA, 2016).

\section{Method of Procurement}

Method of procurement also considers one of success factor of automation and robotic in IBS. Nawi et al., (2016) suggested that the available procurement method that promotes automation and robotics in IBS will be Design and Build (DB), Integrated Project Delivery, Lean Manufacturing, Partnering, Concurrent Engineering (CE), Supply Chain Management.

\section{Mass Customisation}

Bock \& Linner (2010) stated that Customizations' heart is information and communication technology used for forming continuous IT structures on which those information flows created. The customisation genuinely based on the evolution and interconnection of all computer-based technologies. According to Din et al., (2012) With this regards, we need to move from mass production of components to mass customisation of buildings where the building design can be tailor-made to specific customer needs. Bock (2006) added that Mass customisation, not mass production, offers customers increased choice and design flexibility. While mass producers stand behind products and services at prices low enough, that nearly everyone can afford them, mass customizers advocate producing goods services with enough variety and customisation so that everyone finds what they want. 
25. Mass Production

Industrialisation taking into account mass production will lead to reduced costs when the quantities of work are beyond the minimum economic order quantities. The investment in automation and robotics equipment and facilities associated with an industrialisation process can be justified economically only with a large production volume. Such volume allows a distribution of the fixed investment charge over a large number of product units without unduly inflating their ultimate cost (Alinaitwe et al., 2006; Warszawski, 2005).

\section{Education and Training}

Skilled labour which is supported by quality training at all level is essential to ensure the successful implementation of the automation and robotics in IBS. It requires great education and training effort of trades especially for those involved in manufacturing, handling, positioning and erecting the finished components or product (Din et al., 2012; Yusof et al., 2015).

\section{Continuous Improvement and Learning}

Successful implementation depends on the organisation ability to expedite the learning curve from one project to another. Therefore, continuous improvement and learning can develop company understanding on the processes and the principle behind it as the knowledge will multiply as experience mount up (Cooke-Davies, 2002; Yusof et al., 2015).

\section{Sustainability}

According to M. Pan et al., (2018a) the crucial role of the building sector in mitigating climate change and realising sustainable development goals has been highlighted in global agendas (Paris Agreement, 2015; United Nations, 2015). Nevertheless, sustainable development and innovation in the building industry have always been considered being problematic in many aspects (Pan and Ning, 2014). Performance gaps, and poor operational and management procedures hinder the achievement of sustainability and require advanced technologies as a countermeasure. In this regard, automation and robotics is considered as a feasible solution to profoundly improve sustainability performance in multiple ways, such as construction waste reduction, natural resources savings, workplace safety improvements, and high-quality living environment (Bock and Linner, 2012; Castro-Lacouture, 2009; Cousineau and Miura, 1998)

The list of critical success factors CSFs to automation and robotics in industrialised building system is presented in table 1. 


\section{Table 1. Critical Success Factors CSFs to Automation and Robotics in IBS}

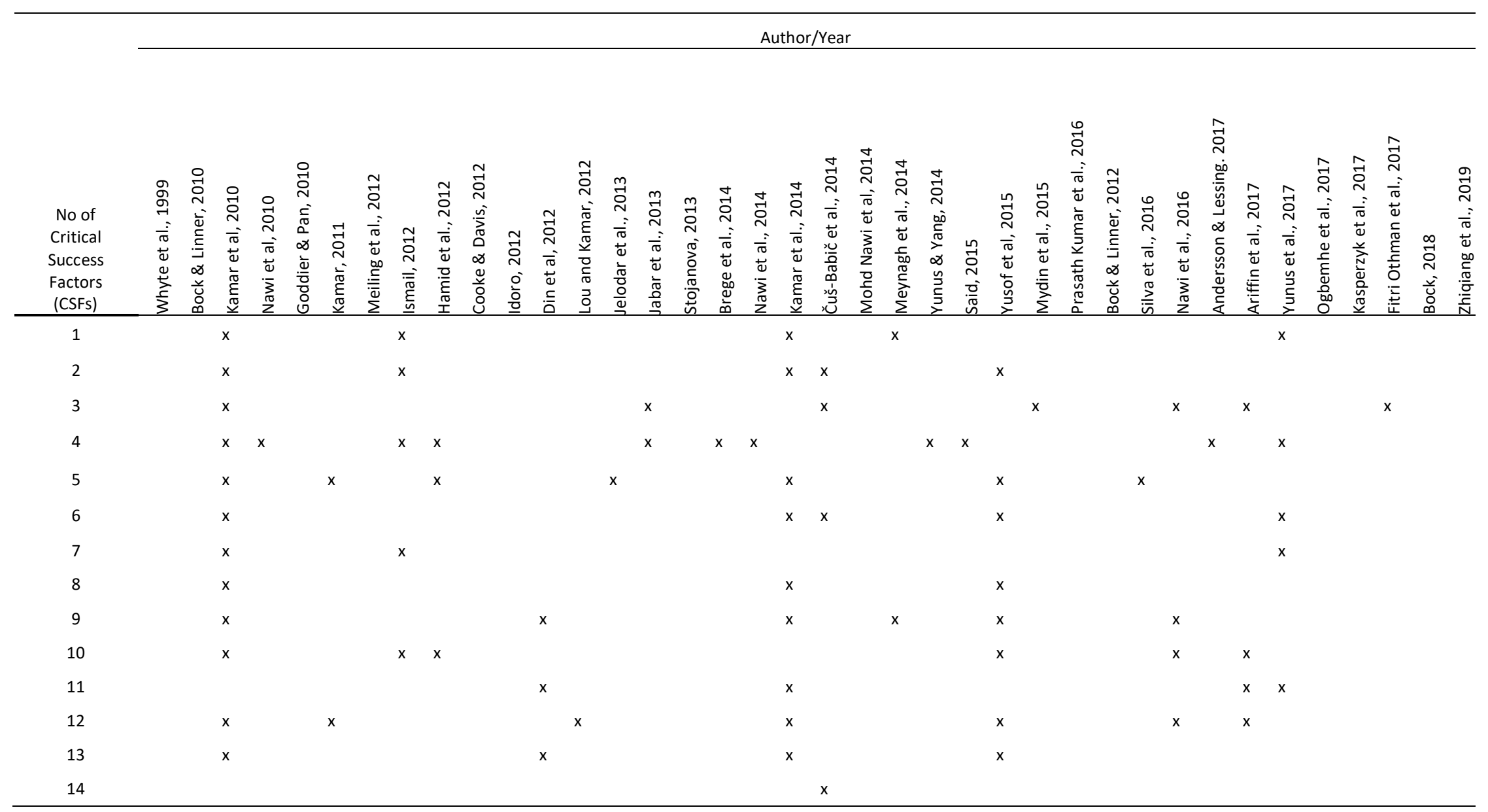

1. Good Working Collaboration, 2. Effective Communication Channel, 3. Coordination of design, Manufacture, Transportation and Installation, 4. Involvement during design stage for all team members, 5. Experienced workforce and Technical capable, 6. Information and communication technology (ICT), 7. Risk management Strategy, 8. Extensive planning and scheduling, 9. Management of supply chain, 10. Top down commitment, 11. Economic of scale, 12. Partnering, 13. Standardisation, 14. Building Information Modelling. 


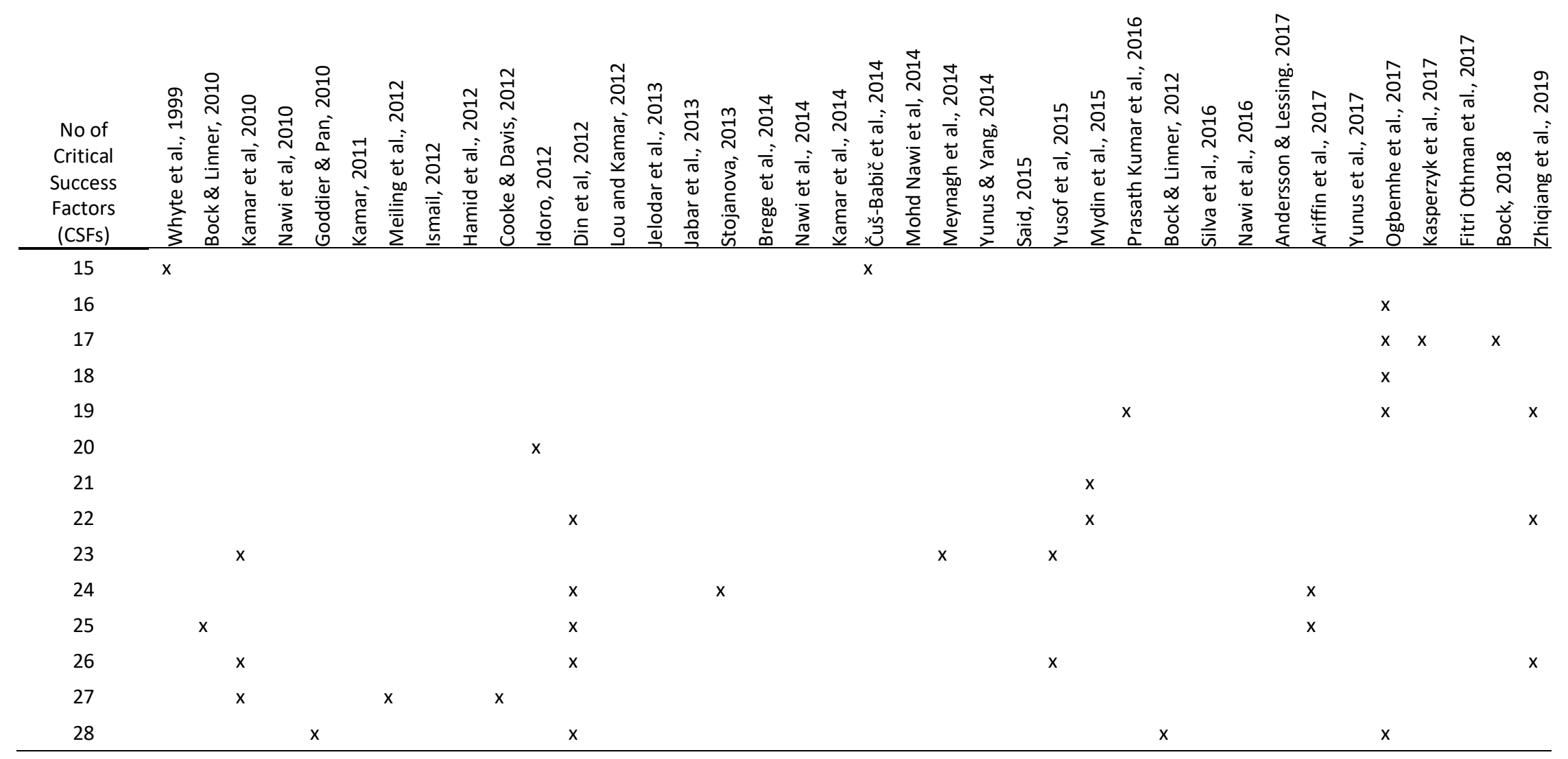

15. Virtual Reality (VR), 16. Improved Speed to the market, 17. Scaling and adapting to changing demand/Flexibility, 18. Delivering consistent Demand, 19. Return on investment through cost reduction and added value, 20. Availability of Plant and Equipment/Machineries, 21. Demand and market Factors, 22. Government Initiatives, 23. Method of Procurement, 24. Mass Customization, 25. Mass Production, 26. Education and Training, 27. Continuous Improvement and learning, 28. Sustainability. 
INTERNATIONAL JOURNAL OF ACADEMIC RESEARCH IN BUSINESS AND SOCIAL SCIENCES

Vol. 8, No. 12, Dec, 2018, E-ISSN: 2222-6990 @ 2018 HRMARS

\section{Conclusion}

Automation and robotics indeed will improve the construction industry and promoting uptakes of the Industrialised Building System (IBS). From the study 28 of success factors have been identified which are 1. Good Working Collaboration, 2. Effective Communication Channel, 3. Coordination of design, Manufacture, Transportation and Installation, 4. Involvement during design stage for all team members, 5. Experienced workforce and Technical capable, 6. Information and communication technology (ICT), 7. Risk management Strategy, 8. Extensive planning and scheduling, 9. Management of supply chain, 10. Top down commitment, 11. Economic of scale, 12. Partnering, 13. Standardisation, 14. Building Information Modelling, 15. Virtual Reality (VR), 16. Improved Speed to the market, 17. Scalling and adapting to changing demand/Flexibility, 18. Delivering consistent Demand, 19. Return on investment through cost reduction and added value, 20. Availability of Plant and Equipment/Machineries, 21. Demand and market Factors, 22. Government Initiatives, 23. Method of Procurement, 24. Mass Customization, 25. Mass Production, 26. Education and Training, 27. Continoues Improvement and learning, 28. Sustainability. This critical success factors (CSFs) is essential to towards the implementation of automation and robotics in IBS.

\section{Corresponding Author}

Mohd Najib Abd Rashid, Fakulti Senibina, Perancngan \& Ukur, Universiti Teknologi MARA Perak, 32610 Seri Iskandar, Malaysia, Email: mohdn613@perak.uitm.edu.my

\section{References}

Abd Hamid, Z., Chee Hung, F., \& Abdul Rahim, A. H. (2017). Retrospective View and Future Initiatives in Industrialised Building Systems (IBS) and Modernisation, Mechanisation and Industrialisation (MMI). Modernisation, Mechanisation and Industrialisation of Concrete Structures, 424-452.

Abd Rashid, M. N., Abdullah, M. R., Ismail, D., \& Mahyuddin, M. N. (2018). Towards Automation And Robotics In Industrialised Building System ( IBS ): A Literature Review. In 3rd International Conference On Rebuilding Place (ICRP 2018). Ipoh, Perak.

Alinaitwe, H. M., Mwakali, J., \& Hansson, B. (2006). Assessing the degree of industrialisation in construction-a case of Uganda. Journal of Civil Engineering and Management, 12(3), 221-229.

Amberg, M., Fischl, F., \& Wiener, M. (2005). Background of critical success factor research. Working Paper No 2/2005 (Vol. 17).

Andersson, N., \& Lessing, J. (2017). The Interface between Industrialized and Project Based Construction. Procedia Engineering, 196(June), 220-227.

Anuar, K., Kamar, M., Hamid, Z. A., Zura, M., Zain, M., Hazim, A., ... Azman, M. N. (2012). Drivers and Barriers of Industrialised Building System (Ibs) Roadmaps in Malaysia. Malaysian Construction Research Journal, 9(1), 1985-3807.

Anuar Mohamad Kamar, K., Alshawi, M., \& Abd Hamid, Z. (2009). INDUSTRIALISED BUILDING SYSTEM : THE CRITICAL SUCCESS FACTORS Research Methodology Relation of this Paper to Overall PhD Research Study. International Postgraduate Research Conference, 29-30.

Bock, T.T, Linner, T. (2010). Mass Customization in a Knowledge-based Construction Industry for Sustainable High- performance Building Production, 108-121.

Bock, T. (2006). Construction robotics. Journal of Robotics and Mechatronics, 28(2), 116-122. 
INTERNATIONAL JOURNAL OF ACADEMIC RESEARCH IN BUSINESS AND SOCIAL SCIENCES

Vol. 8, No. 12, Dec, 2018, E-ISSN: 2222-6990 @ 2018 HRMARS

Bock, T., Georgoulas, C., \& Linner, T. (2014). Advanced Construction and Building Technology for Society.

Buckett, N. R. (2013). Building Better for Less - Advanced Residential Construction Techniques, 294.

CIDB. (2015). Construction Industry Tranformation Program 2016 - 2020. CIDB. (2018). Taking Malaysian Construction To New Levels. HEIGHTS, 3.

Cooke-Davies, T. (2002). The "real" success factors on projects. International Journal of Project Management, 20(3), 185-190.

Čuš-Babič, N., Rebolj, D., Nekrep-Perc, M., \& Podbreznik, P. (2014). Supply-chain transparency within industrialized construction projects. Computers in Industry, 65(2), 345-353.

Dallasega, P., Rauch, E., \& Linder, C. (2018). Industry 4.0 as an enabler of proximity for construction supply chains: A systematic literature review. Computers in Industry, 99(August 2017), 205-225.

Din, M. I., Bahri, N., Dzulkifly, M. A., Norman, M. R., Kamar, K. A. M., \& Abd Hamid, Z. (2012). The adoption of industrialised building system (IBS) construction in Malaysia: The history, policies, experiences and lesson learned. 2012 Proceedings of the 29th International Symposium of Automation and Robotics in Construction, ISARC 2012, 1, 8.

Fritz, W. (2006). sucess factors of internet based Business Models. Technical Report.

Hassim, S., \& Jaafar, M. S. (2009). The Contractor Perception Towers Industrialised Building System Risk in Construction Projects in Malaysia. American Journal of Applied Sciences, 6(5), 937-942.

Idoro, G. I. (2012). Sustainability of Mechanisation in the Nigerian Construction Industry. Journal of Civil Engineering and Management, 18(1), 91-105.

Ismail, F., Yusuwan, N. M., \& Baharuddin, H. E. A. (2012). Management Factors for Successful IBS Projects Implementation. Procedia - Social and Behavioral Sciences, 68, 99-107.

Jabar, I. L., Ismail, F., \& Mustafa, A. A. (2013). Issues in Managing Construction Phase of IBS Projects. Procedia - Social and Behavioral Sciences, 101, 81-89.

Kamar, K. A. M., Azman, M. N. A., \& Nawi, M. N. M. (2014). IBS survey 2010: Drivers, barriers and critical success factors in adopting industrialised building system (IBS) construction by G7 contractors in Malaysia. Journal of Engineering Science and Technology, 9(4), 490-501.

Kamar, K., \& Hamid, Z. (2011). Supply chain strategy for contractor in adopting industrialized building system (IBS). Australian Journal of Basic and Applied ..., 5(12), 2552-2557.

Lou, E C W, Kamar, K. (2012). Industrialized Building Systems : Strategic Outlook for Manufactured Construction in Malaysia. JOURNAL OF ARCHITECTURAL ENGINEERING, 18(June), 69-74.

Luo, L., Mao, C., Shen, L., \& Li, Z. (2015). Risk factors affecting practitioners' attitudes toward the implementation of an industrialized building system. Engineering, Construction and Architectural Management, 22(6), 622-643.

Mahbub, R. (2008). An investigation into the barriers to the implementation of automation and robotics technologies in the ... PhD Thesis.

Meynagh, M. M., Marsono, A. K., Kamar, K. A. M., \& Isaabadi, M. H. Z. (2014). Main Factors of Contractor Reluctancy to Adopt IBS Projects In Malaysia. Australian Journal of Basic and Applied Sceinces, 8(18), 251-254.

MIDA. (2016). ADOPT AUTOMATION , INCREASE PRODUCTIVITY.

Mohamad Kamar, K. A. (2011). CRITICAL SUCCESS FACTORS TO INDUSTRIALISED BUILDING SYSTEM ( IBSS) School of the Built Environment, Faculty of Business, Law and the Built Environment, 
INTERNATIONAL JOURNAL OF ACADEMIC RESEARCH IN BUSINESS AND SOCIAL SCIENCES

Vol. 8, No. 12, Dec, 2018, E-ISSN: 2222-6990 @ 2018 HRMARS

University of Salford. PhD Thesis, (January)

Mohd Amin, M. A., Abas, N. H., Shahidan, S., Rahmat, M. H., Suhaini, N. A., Nagapan, S., \& Abdul Rahim, R. (2017). A review on the current issues and barriers of Industrialised Building System (IBS) adoption in Malaysia's construction industry. IOP Conference Series: Materials Science and Engineering, 271, 012031. $\mathrm{h}$

Nawi, M.N.M., Lee, A., Arif, M. (2010). The IBS Barriers in the Malaysian Construction Industry : A Study in Construction Supply Chain Perspective. In Special Track 18th CIB World Building Congress.

Nawi, M., Azman, A., Osman, W. N., Radzuan, K., \& Yaakob, M. (2016). Key success factors for team integration practice in Malaysian industrialised building system (IBS) construction industry. Malaysian Journal of Society and Space, 12(3), 88-94.

Nawi, M. N. M., Lee, A., Azman, M. N. A., \& Kamar, K. A. M. (2014). Fragmentation issue in Malaysian industrialised building system (IBS) projects. Journal of Engineering Science and Technology, 9(1), 97-106.

Ogbemhe, J., Mpofu, K., \& Tlale, N. S. (2017). Achieving Sustainability in Manufacturing Using Robotic Methodologies. Procedia Manufacturing, 8(October 2016), 440-446.

Pan, M., Linner, T., Pan, W., Cheng, H., \& Bock, T. (2018a). A framework of indicators for assessing construction automation and robotics in the sustainability context. Journal of Cleaner Production, 182, 82-95.

Pan, M., Linner, T., Pan, W., Cheng, H., \& Bock, T. (2018b). A framework of indicators for assessing construction automation and robotics in the sustainability context. Journal of Cleaner Production, 182(February), 82-95.

Prasath Kumar, V. R., Balasubramanian, M., \& Jagadish Raj, S. (2016). Robotics in construction industry. Indian Journal of Science and Technology, 9(23).

Rakyat, D. (2017). Dewan Rakyat Mesyuarat Pertama. Dewan Rakyat Parlimen Ketiga Belas Penggal Kelima Mesyuarat Pertama, (Halaman 1).

Rashidi, A., \& Ibrahim, R. (2017). Industrialized Construction Chronology: The Disputes and Success Factors for a Resilient Construction Industry in Malaysia. The Open Construction and Building Technology Journal, 11(1), 286-300.

Rockart, B. \&. (1981). Critical success factors. Planning Review.

Silva, G. A. S. K., Warnakulasooriya, B. N. F., \& Arachchige, B. J. H. (2016). Criteria for Construction Project Success : A Literature Review. 13th International Conference on Business Management (ICBM), 697-717.

Son, H., Kim, C., Kim, H., Han, S. H., \& Kim, M. K. (2010). Trend analysis of research and development on automation and robotics technology in the construction industry. KSCE Journal of Civil Engineering, 14(2), 131-139.

Soon Ern, P. A., Kasim, N., Abd Hamid, Z., \& Kai Chen, G. (2017). Critical ICT-Inhibiting Factors on IBS Production Management Processes in the Malaysia Construction Industry. IOP Conference Series: Materials Science and Engineering, 245, 032067.

Tajul Ariffin, S., Yunus, R., Mohammad, H., \& Yaman, S. K. (2017). A Preliminary Review on Economies of Scale (EOS) Towards Industrialized Building System (IBS) Manufacturer. MATEC Web of Conferences, 103(April), 03008. 
UK-RAS Network. (2016). Manufacturing Robotics: The Next Robotic Industrial Revolution.

Vähä, P., Heikkilä, T., \& Kilpeläinen, P. (2013). Survey on Automation of the Building Construction and Building Products Industry.

Warszawski, A. (2005). Industrialized and Automated Building System - A Managerial Approach. Taylor \& Francis Group.

Xue, H., Zhang, S., Su, Y., \& Wu, Z. (2017). Factors Affecting the Capital Cost of Prefabrication - A Case Study of China. MDPI, 1-22.

Yunus, R., Noor, S. R. M., Abdullah, A. H., Nagapan, S., Hamid, A. R. A., Tajudin, S. A. A., \& Jusof, S. R. M. (2017). Critical Success Factors for Lean Thinking in the Application of Industrialised Building System (IBS). IOP Conference Series: Materials Science and Engineering, 226, 012045.

Yusof, M. R., Nawawi, A. H., Mohammad, M. F., \& Musa, M. F. (2015). Key Success Factors in IBS Project Management. IEEE Colloquium on Humanities, Science and Engineering (CHUSER 2014), (Chuser 2014), 210-215. 